\title{
Exploitation of trophic resources by fish under stressful estuarine conditions
}

\author{
Stéphanie Pasquaud ${ }^{1, *}$, Valérie David ${ }^{2}$, Jérémy Lobry ${ }^{1}$, Michel Girardin ${ }^{1}$, \\ Benoît Sautour ${ }^{3}$, Pierre Elie ${ }^{1}$ \\ ${ }^{1}$ Cemagref, Estuarine Ecosystems and Diadromous Fish Research Unit, 50 avenue de Verdun 33612 Cestas Cedex, France \\ ${ }^{2}$ UMR LIENSs 6250 CNRS/Université de La Rochelle, Institut du Littoral et de l'Environnement, 2 rue Olympes de Gouges, \\ 17000 La Rochelle, France \\ ${ }^{3}$ UMR 5805 EPOC-OASU, Université de Bordeaux 1, 2 Rue du Professeur Jolyet, 33120 Arcachon, France
}

\begin{abstract}
Despite their high complexity and variability, estuaries are very productive and play an important role in fish feeding. We investigated how fish optimize their use of the available trophic resources by studying trophic preference variability and feeding strategies of some pelagic and demersal fish in the Gironde estuary (southwest France). Fish and their prey were collected approximately every 2 mo from July 2003 to June 2004 in the upstream area of the saline estuary. Stomach contents were analysed to assess the variability of fish feeding in relation to their size and the time of year. Intra- and interspecific food niche overlap was evaluated using Schoener's index, and a crosscalculation method was used to highlight general fish trends in predation strategy. Stomach content results showed interspecific and intraspecific variability in feeding by fish, which can be explained by their different or ontogenetically changing ecomorphology. Their diets are composed mainly of zooplankton and hyperbenthic crustaceans, with temporal variations in the consumed taxa. Optimization of available trophic resource use, a key element in estuarine resilience, is thus possible due to the temporal adaptation of this structural trophic web. However, in spite of their temporal adaptation capacity, most fish species exhibited a specialist feeding strategy. This result was not expected. Since zooplankton and hyperbenthic crustaceans exhibit a low specific richness in estuaries, especially in the high turbidity of the Gironde estuary, the loss of one of these species could affect the fish trophic web structure and hence the resilience of the system.
\end{abstract}

KEY WORDS: Pelagic and demersal fish · Stomach contents · Diet composition · Feeding strategy • Prey characteristics · Estuarine ecosystem · Gironde estuary

Resale or republication not permitted without written consent of the publisher

\section{INTRODUCTION}

Estuaries are particular ecosystems, where the abiotic environment is characterized by rapid and large spatio-temporal fluctuations in physico-chemical characteristics (e.g. oxygen, temperature, salinity) in both water column and bed sediment dynamics (McLusky \& Elliott 2004). This high environmental variability leads to a high spatio-temporal heterogeneity of the biological communities (McLusky \& Elliott 2004, David et al. 2005), with a low diversity of all components, yet often with high abundances of adapted species (Mc Lusky \& Elliott 2004). Thus, this strong biological variability is related to the ability of the estuarine biota to cope with natural stress, a key element in estuarine resilience (Elliott \& Quintino 2007).

In addition, estuaries are generally exposed to high degrees of anthropogenic pressures that can modify their ecological status. Recent works underline the similarity between the features of organisms and assemblages in estuaries, subject to natural stress, and, those in anthropogenically stressed areas and, hence, the difficulty of distinguishing natural from human-induced stress in estuaries ('Estuarine quality paradox'; Elliott \& Quintino 2007, Dauvin \& Ruellet 2009). 
Because of these characteristics, monitoring and assessing the biodiversity and ecological status of marine ecosystems requires a substantial knowledge and a comprehensive understanding of properties across the entire biological system, in particular its structure (e.g. species composition) and functional properties (e.g. ecosystem processes; Hooper et al. 2005, de Jonge et al. 2006). Studying interactions between the biological compartments of an ecosystem, especially trophic relationships, provides a good picture of the biological community structure and is an essential step to understanding how an aquatic system functions (e.g. Elliott \& Hemingway 2002, Livingston 2002, Pasquaud et al. 2007, 2008).

Topological approaches in trophic models are used to better understand estuarine ecological structure and functioning (Baird \& Ulanowicz 1993, Wolff et al. 2000, Lin et al. 2007, Lobry et al. 2008). Most authors (in particular Lobry et al. 2008) suggest that estuarine communities have to optimize use of available trophic resources to successfully cope with stressful conditions This suggests that: (1) a temporal adaptation of the trophic web would be observed and (2) most estuarine species would be opportunists. The present paper constitutes a preliminary investigation to test both of these assumptions by analyzing the food preferences and feeding strategies of the main fish species of the Gironde estuary.

The first objective was thus to describe the trophic relationship variability according to fish size and time of year of the main Gironde estuarine demersal and pelagic fish species using stomach content analysis, which appears to be the most reliable method to determine fish feeding (Pasquaud et al. 2007). The second objective was to analyze the dynamics of the fish feeding preferences using characteristics of their diet and of their prey population (abundance in the environment, mean weight).

\section{MATERIALS AND METHODS}

Study area. The Gironde estuary $\left(45^{\circ} 20^{\prime} \mathrm{N}, 0^{\circ} 45^{\prime} \mathrm{W}\right.$; Fig. 1) is located in SW France and opens onto the Bay of Biscay. Its surface area is approximately $625 \mathrm{~km}^{2}$ at high tide. It is $76 \mathrm{~km}$ long between the ocean and the Bec d'Ambès, where the Dordogne and Garonne Rivers meet and which generally constitutes the upstream salinity limit. The watershed covers $81000 \mathrm{~km}^{2}$, and the mean annual rate of freshwater discharge is around $760 \mathrm{~m}^{3} \mathrm{~s}^{-1}$. These characteristics make it the largest estuary in western Europe (Salomon 2002, Lobry et al. 2003). The tidal range is $4.5 \mathrm{~m}$ at the mouth of the estuary and $>5 \mathrm{~m}$ at Bordeaux. The Gironde is one of the most turbid estuaries in Europe (Sautour \&
Castel 1995). River systems carry annually between 1.5 and $3 \times 10^{6} \mathrm{t}$ of suspended particulate matter (SPM; David et al. 2005) to the estuary, with a fairly permanent maximum turbidity zone (SPM about $1 \mathrm{~g} \mathrm{l}^{-1}$ at the surface and $10 \mathrm{~g} \mathrm{l}^{-1}$ near the bed; Sottolichio 1999). As a consequence, primary production in the Gironde is reduced $\left(10 \mathrm{~g} \mathrm{C} \mathrm{m}^{-2} \mathrm{yr}^{-1}\right)$, and the food-web base consists, for the most part, of a varied nutritional pool containing a high proportion of detritus (Irigoien \& Castel 1995).

The climate of the region is temperate under oceanic influence. Typically, water temperature variability is moderate (between $2{ }^{\circ} \mathrm{C}$ in January and $26^{\circ} \mathrm{C}$ in $\mathrm{Au}-$ gust) and monthly rainfall fluctuates between $50 \mathrm{~mm}$ in summer and $100 \mathrm{~mm}$ in winter (Klein Tank et al. 2002). During the sampling period (from July 2003 to June 2004), the water temperature ranged from $9.78^{\circ} \mathrm{C}$ in February to $25.42^{\circ} \mathrm{C}$ in July in the study area. The river flow remained very low from July to December 2003, in spite of a few strong freshwater inputs in December. The first half of 2004 was relatively dry, characterized only by episodes of flooding in January and April to May (authors' unpubl. data). Because of these hydrological conditions, a very strong marine intrusion was observed during summer 2003, with maximum salinity values in September (average salinity 11.43 in the sampling area), and low salinities were recorded in February (0.08), April (0.41) and June (3.48).

Fish sampling. To analyze temporal feeding variability, fish were collected approximately every 2 mo from

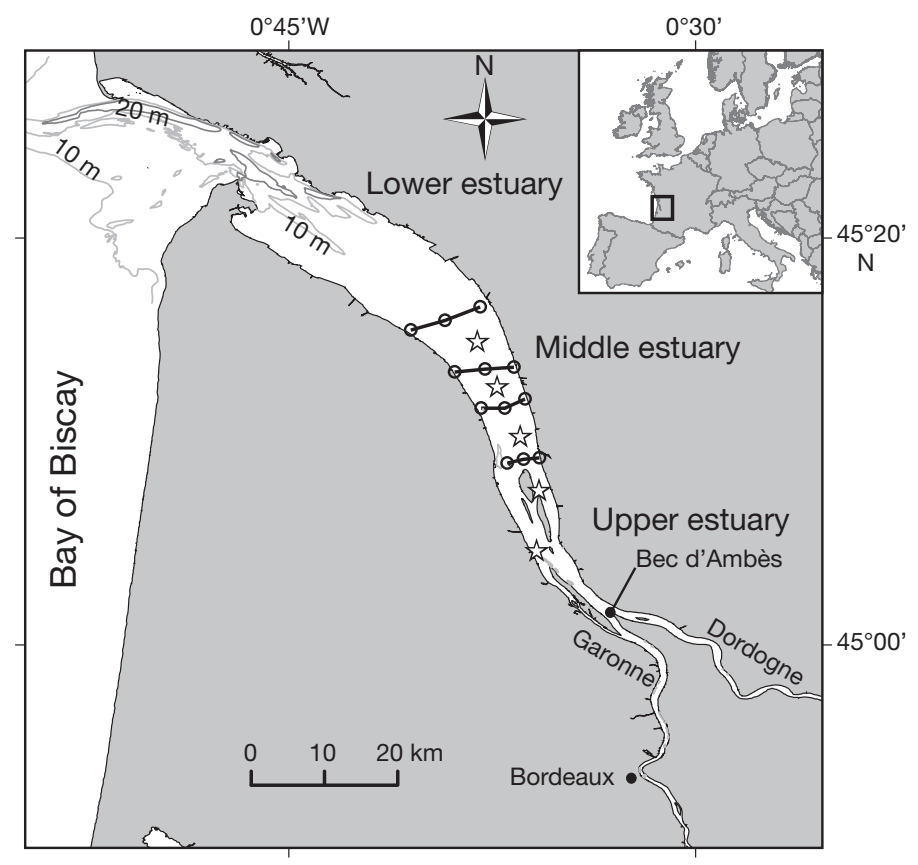

Fig. 1. Location of sampling stations in the Gironde estuary. Stars: fish; circles: shrimps; lines: the 4 transects 
July 2003 to June 2004 in the upper and middle area of the Gironde estuarine haline part (Table 1, Fig. 1). Specimens were caught once per sampled month at 5 stations (Fig. 1) using an otter trawl (4 m opening and a cod-end with a mesh size of $8 \mathrm{~mm}$ ). Trawling was restricted to daylight at high tide in order to standardize the samplings, and only when the tidal coefficient was $<75$ (trawling at a coefficient $>80$ in this system is not reliable). Haul duration was limited to $15 \mathrm{~min}$ to optimize the analysis of the stomach contents by minimizing regurgitation and feeding under abnormal conditions in the trawl (Pasquaud et al. 2007). All the sampled fish were identified, counted, measured (total length) and weighed. Fish <200 mm long were immediately placed on dry ice in order to stop the digestion processes. The digestive tract of the largest specimens was conserved on dry ice. The samples were stored at $-18^{\circ} \mathrm{C}$ in the laboratory. Using this protocol, all the analyses could be carried out on fresh material, after defrosting, thus facilitating handling and also the identification of the fish species and their prey.

Stomach content analyses. The fish species analyzed were selected because they were considered typical of the estuarine ichthyofauna both in terms of occurrence and of functional guilds, i.e. ecological and feeding categories (see Lobry et al. 2003 for details; Table 1). Prey sampled in the system for which data were available (cf. 'prey data' paragraph) were zooplankton and hyperbenthos. We thus focused on their fish predator species.

Table 1. Functional guilds (EG: ecological guild; TG: trophic guild) and number of fish used for stomach content analyses for each sampled month. N: number of sampled stations for fish, shrimp and zooplankton; S: small; L: large; ER: truly estuarine resident fish; MS: marine seasonal migrant fish; $\mathrm{MJ}$ : marine juvenile migrant fish; P: planktivore; IS: invertebrate feeder; IF: invertebrate and fish feeder

\begin{tabular}{|lcccccccc|}
\hline & EG & TG & Jul & Sep & Nov & Feb & Apr & Jun \\
& & & 2003 & 2003 & 2003 & 2004 & 2004 & 2004 \\
\hline Fishes & & & & & & & & \\
N & & & 5 & 5 & 5 & 5 & 5 & 5 \\
Sprattus sprattus & MS & P & & 5 & & & & \\
Engraulis encrasicolus & MS & P & 27 & 9 & 6 & & & \\
Pomatoschistus microps & ER & IS & 20 & & 10 & 11 & 15 & \\
Pomatoschistus minutus (S) & ER & IS & & 15 & & 21 & & 15 \\
Pomatoschistus minutus (L) & ER & IS & 30 & 25 & 20 & 6 & & 20 \\
Dicentrarchus labrax & MJ & IF & 6 & 5 & 9 & 26 & 11 & \\
Dicentrarchus punctatus & MJ & IF & & & & & 5 & \\
Argyrosomus regius (S) & MS & IF & 68 & & & & & 15 \\
Argyrosomus regius (L) & MS & IF & & 29 & 36 & & 20 & 40 \\
Merlangius merlangus & MS & IF & & 5 & 8 & & & \\
Shrimp & & & & & & & & \\
N & & & 12 & 12 & 12 & 12 & 12 & 12 \\
Zooplankton & & & & & & & & \\
N & & & 23 & 22 & 16 & 12 & 16 & 16 \\
\hline
\end{tabular}

The stomach contents of 538 individuals from the 8 fish species caught in the sampling area were analyzed (Table 1). A minimum of 5 specimens per taxa and per sampled month, with food items in their stomachs, were selected for analysis (minimum required to obtain a diet picture). Two size ranges were distinguished for $\mathrm{Po}$ matoschistus minutus (small $<40 \mathrm{~mm}$; large $\geq 40 \mathrm{~mm}$ ) and Argyrosomus regius (2 age classes) to test ontogenic changes in feeding. All the items in the stomachs were examined under a binocular microscope, identified to the highest possible taxonomic level, counted and weighed (dry weight, to nearest $10^{-4} \mathrm{~g}$ ). Dietary analysis is traditionally assessed by occurrence (i.e. the percentage of non-empty stomachs where a certain prey item occurred), numerical and volumetric/gravimetric methods (see Hynes 1950, Hyslop 1980 for more details). Each of these measures provides a different insight into predator feeding habits (Cortès 1997). The numerical percentage of the prey $(\% N)$ is well adapted to our objective as it describes feeding behavior (Macdonald \& Green 1983). This was calculated for each item consumed by a fish species per month.

The mean weight ( $\bar{W}$ in g) of each prey was also estimated from these stomach content analyses (average of the dry weights of each item consumed by a predator species per month).

Prey data. Sampling data for shrimps and zooplankton from the same estuarine area and the same months as the fish sampling data were used to characterize prey populations in the environment (Table 1).

Shrimps were collected from 4 transects, established since 1991 for monitoring the smaller components of the estuarine fauna around the Blayais nuclear power plant on a monthly basis (Lobry et al. 2006). Each transect consists of 3 sites, 1 close to each bank and 1 in the main channel of the estuary (Fig. 1). At each site, sampling was carried out simultaneously near the surface and near the bottom, with the water surface sampled using 2 pushnets located one on each side of the boat (section $4 \times 1 \mathrm{~m}$, stretched mesh of $1 \mathrm{~mm}$ in the cod-end) and the bottom sampled using a dragnet with a $2.0 \times 1.2 \mathrm{~m}$ frame, kept at $0.2 \mathrm{~m}$ above the bed by runners. The net meshes were identical to those used for surface sampling. Sampling was carried out in daytime, between the halfway stage of the flood tide and high tide slack. Each tow lasted about $7 \mathrm{~min}$. All the samples collected were preserved in $10 \%$ formaldehyde, before being identified and counted at the laboratory. 
Zooplankton was collected along the estuary every 3 units of salinity using a standard $200 \mu \mathrm{m}$ WP-2 net for zooplankton and a $500 \mu \mathrm{m}$ bongo net, which is better adapted to mysid and amphipod sampling. Vertical hauls were carried out at each station for each net. The catch was preserved in 5\% seawater/formalin before being identified and counted at the laboratory.

Abundance of the different prey categories was calculated for each month, and expressed as the number of individuals per cubic meter of filtered water at the sampling site.

Data analyses. In order to determine whether the consumption of the different prey varied with time or predator size, permutation tests based on inertia analysis (Chessel et al. 2004), with a 0.05 significance level, were performed on matrices of the diet composition per each fish predator using the relative abundance $(\% N)$ of the prey items.

Intra- and interspecific food niche overlap was evaluated using Schoener's index (SI), defined as

$$
\mathrm{SI}_{x y}=1-0.5\left(\sum_{i=1}^{n}\left|N_{x i}-N_{y i}\right|\right)
$$

where $N_{x i}$ is the relative abundance of prey category $i$ in the stomach content of species $\mathrm{x}$ and $N_{\mathrm{yi}}$ the same relative abundance in the species $y$ (Hurlbert 1978). According to Wallace (1981) and Wallace \& Ramsay (1983), overlap values $>0.6$ should be considered biologically significant.

The general trends in predation strategy for each species (or size group) and each sampled month were studied using the cross-calculation method described by Azémar et al. (2007). This method allows us to test if a predator diet can be determined by prey characteristics (e.g. abundance or mean weight/size) in the environment. It consists of: (1) ranking prey $i$ of each fish of a predator group (species or size class) as a function of relative abundance $(N)$ in the stomach contents $\left(N_{i}\right.$ ranks; e.g. for Engraulis encrasicolus, Stomach Content 1: $N_{\text {Acartia }}=$ Rank 1; Stomach Content 9: $N_{M \text {. slabberi }}=$ Rank 1, $N_{\text {cirripedes }}=$ Rank 2, $N_{\text {Acartia }}=$ Rank 3), and (2) ranking these same prey according to their abundance (Ab ranks) and their mean weight $(\bar{W}$ ranks) in the environment (e.g. in July, $\mathrm{Ab}_{\text {Acartia }}=$ Rank 1, $\mathrm{Ab}_{\text {M. slabberi }}=$ Rank 2, Ab $b_{\text {cirripedes }}=$ Rank 3). As only prey that appeared in the stomach contents are considered, predator feeding strategy is assessed within the context of its trophic niche. Moreover, non-sampled prey in the present study (e.g. nauplius crustacean stage) were excluded from the analysis. Next, (3) the frequencies (i.e. number of occurrences observed from all the stomach contents) of each combination $N_{i}$ ranks $\times \mathrm{Ab}_{i}$ ranks and $N_{i}$ ranks $\times W_{i}$ ranks were calculated for each prey of a predator group. Finally, (4) the shape of the distribution was tested using a Spearman rank test at $p<0.05$. If these frequencies increased or decreased as a function of the prey characteristic ranking (Ab or $\bar{W}$ ), the predation was considered to be selective according to prey abundance (Ab) or mean weight $(\bar{W})$; otherwise, the predation was unselective with regard to the prey characteristic considered (Ab or $\bar{W}$ ).

Three different types of predation strategy were determined: (1) generalist, when the Spearman correlation coefficient was not significant for either abundances or mean weights; (2) opportunistic, when frequencies increased significantly with abundances; and (3) specialist, when the highest frequencies were concentrated around a narrow mean weight (Fig. 2).

\section{RESULTS}

\section{Interspecific feeding variability}

Fish species showed different feeding ecology and strategy (Fig. 2, Table 2 \& Appendix 1). Small marine pelagic fish Sprattus sprattus and Engraulis encrasicolus based their diet on mesozooplankton, feeding mainly on the nauplius stage of crustaceans and on copepods of the genus Acartia. However, their trophic niches did not overlap (SI < 0.6) and their predation strategy was different: E. encrasicolus was an opportunist, i.e. among its food spectrum, this species mainly consumed the most abundant prey in the system (e.g. Acartia in September), whereas $S$. sprattus was a specialist, focusing on prey of a specific weight (size) range (e.g. selection of cirriped larvae in September, not the most abundant prey).

Small estuarine resident species Pomatoschistus minutus and P. microps also consumed a high quantity of mesozooplankton, but their diet differed from that of Sprattus sprattus and Engraulis encrasicolus due to a high consumption of hyperbenthos, essentially the mysid Mesopodopsis slabberi and the amphipods Gammarus spp. (no overlap; SI <0.6). The 2 species of Pomatoschistus were seldom present together in the area studied, and, if they were, they tended to show a trophic niche overlap (February, SI $>0.8$ ). Both were characterized by specialist feeding, essentially on the largest zooplankton (the copepod Eurytemora affinis) and the smallest hyperbenthos (mysids M. slabberi and Neomysis integer).

Finally, the feeding of marine demersal fish (e.g. $D i$ centrarchus labrax, D. punctatus, Argyrosomus regius and Merlangius merlangus) was mainly characterized by hyperbenthic prey such as the mysids Mesopodopsis slabberi and Neomysis integer, the amphipods Gammarus spp. and the shrimps Palaemon spp.

The 2 species of Dicentrarchus did not show trophic niche overlap, and presented different predation strategies: D. labrax was a specialist and D. punctatus 

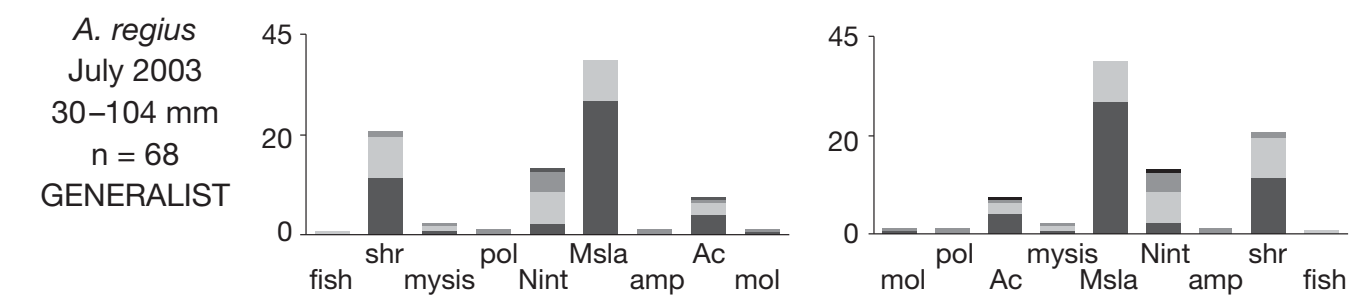

\section{Spearman test}
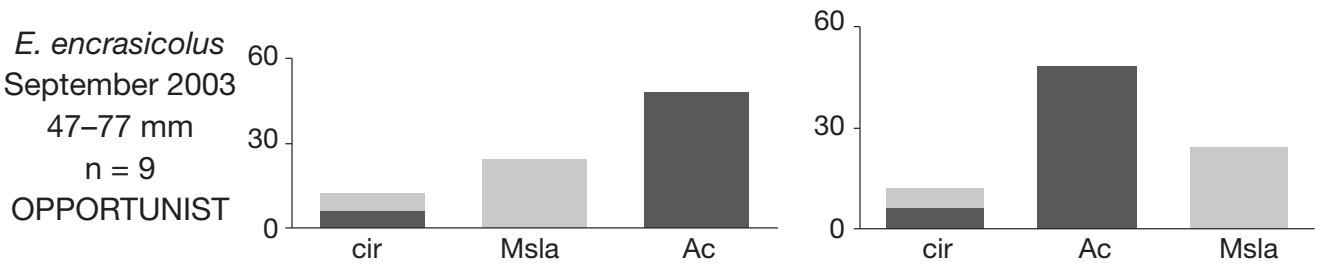

$\begin{array}{lcc} & \text { Ab } & \overline{\boldsymbol{W}} \\ \text { Rg1-4 } & \text { ns } & \text { ns } \\ \text { Rg1 } & \text { ns } & \text { ns }\end{array}$
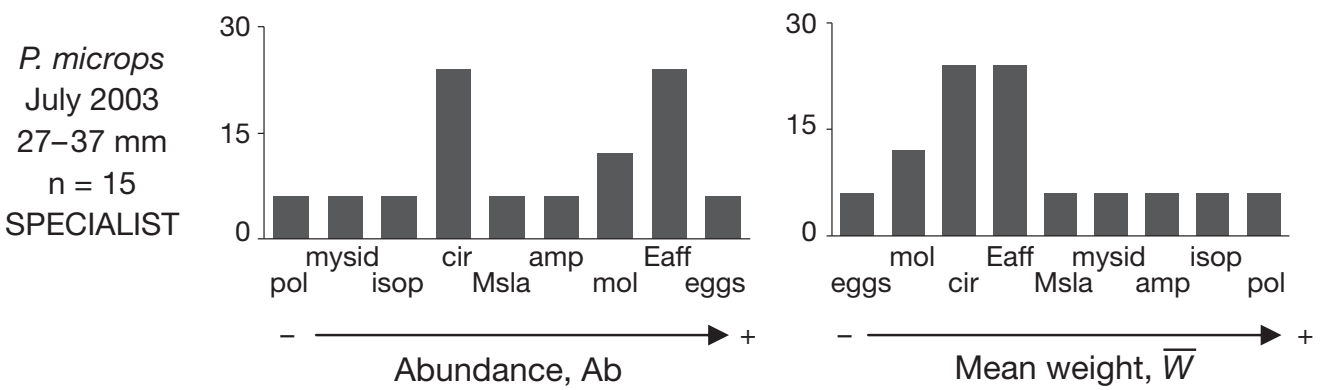

$\begin{array}{lcc} & \text { Ab } & \overline{\boldsymbol{W}} \\ \text { Rg1-2 } & * * & \text { ns } \\ \text { Rg1 } & \text { ns } & \text { ns }\end{array}$

Fig. 2. Examples of cumulated frequencies of relative abundance $(N)$ ranks ( $y$-axis) versus prey abundances (Ab) or mean weights $(\bar{W})$ in the environment for each predation strategy: Argyrosomus regius in July 2003 for generalist species (Spearman correlation coefficients were not significant for $\mathrm{Ab}$ or $\bar{W}$ ), Engraulis encrasicolus in September 2003 for opportunistic species (frequencies significantly increased with Ab), and Pomatoschistus microps in July 2003 for specialist species (the highest frequencies were concentrated around a narrow $\bar{W}$ value). Cir: cirripede larvae; mol: mollusk larvae; pol: polychaete larvae; Ac: Acartia spp.; Eaff: Eurytemora affinis; mysis: mysis larvae; Nint: Neomysis integer; Msla: Mesopodopsis slabberi; mysid: other mysids; shr: shrimps; amp: amphipods, essentially Gammarus spp.; isop: isopods; Rg1, Rg2, Rg3: first, second and third $N$ ranks; n: number of stomach contents used to calculate frequencies. Significant positive correlations between $N$-rank frequencies and an increase/ decrease in the prey characteristic frequencies are shown on the right. Spearman rank correlation was applied to each of the cumulative series of the positive $\% N$ ranks, from the first and total $N$ rank; ${ }^{* *}$ significant trend at $p<0.01$

was an opportunist. In contrast to Dicentrarchus spp., the trophic niches of Argyrosomus regius and Merlangius merlangus sometimes overlapped, either with each other or with Pomatoschistus minutus. M. merlangus is a specialist predator, whereas $A$. regius was able to feed on either a wide range of prey (generalist) or a narrow range of prey (specialist).

\section{Temporal feeding variability}

Except for Pomatoschistus microps, all fish species showed a significant temporal feeding variability ( $\mathrm{p}$-values of the permutation tests $<0.05$ ):

- Engraulis encrasicolus consumed a large quantity of mollusk eggs (40\%) and nauplius larvae (44\%) in July, whereas it mostly ate the copepods Acartia spp. (94\%) in September and Eurytemora affinis (88\%) in November. Its feeding strategy was opportunistic whatever the season.
- Pomatoschistus microps based its feeding essentially on eggs (40 and $24 \%$ of indeterminate and mollusk eggs, respectively) in July and on Eurytemora affinis in November (55\%), February (94\%) and April $(62 \%)$. However, this species showed no significant temporal feeding variability $(p$-value $=0.301)$. It was a specialist, focusing on prey from a specific weight (size) range whatever the considered month.

- The feeding of Pomatoschistus minutus consisted of mollusk eggs (39\%) and the mysid Mesopodopsis slaberri (22\%) in July, almost exclusively M. slabberi (60\% for small individuals and $79 \%$ for large individuals) in September, M. slaberri (37\%) and Gammarus spp. (21\%) in November, mainly Eurytemora affinis (84\% for the small individuals and $82 \%$ for the large individuals) in February, and finally Gammarus spp. (82 or $64 \%$ ) and Neomysis integer (18 or $28 \%$ ) in June. Both size classes of $P$. minutus showed a specialist strategy, except in November, when the numerous prey in their stomach were the most abundant in the system (opportunism). 
Table 2. Predation strategy for each fish species according to size and time. Results were deduced from the form of $N$ frequencies of prey versus abundances $(\mathrm{Ab})$ and mean weights $(\bar{W})$. Three different types of food behavior were determined: (1) opportunistic when frequencies increased significantly with $\mathrm{Ab}$, (2) generalist when the Spearman correlation coefficient was null, (3) specialist when the highest frequencies were concentrated around a narrow $\bar{W}$ (cf. Fig. 2). See Fig. 2 for the definition of prey abbreviations; naup: nauplius larvae; copepods: other copepods. Prey range: the lowest and the highest weght (size) prey; ns: non-significant trend; ${ }^{*}$ significant trend at $\mathrm{p}<0.05$

\begin{tabular}{|c|c|c|c|c|c|}
\hline & \multirow{2}{*}{\multicolumn{2}{|c|}{$\begin{array}{l}\text { Environment } \\
\text { Available prey } \text { Prey density (ind. } \mathrm{l}^{-1} \text { ) }\end{array}$}} & \multirow{2}{*}{$\begin{array}{l}\text { Size }(\mathrm{mm}) \\
\text { (replicates) }\end{array}$} & \multirow{2}{*}{ Prey no. (range) } & \multirow{2}{*}{ Prey strategy } \\
\hline & & & & & \\
\hline \multicolumn{6}{|c|}{ Engraulis encrasicolus (Eenc) } \\
\hline Jul 2003 & 10 & 7.8 & $38-127(18)$ & 6 (naup-Nint) & Opportunist* \\
\hline Sep 2003 & 11 & 3.1 & $47-77$ (9) & 3 (cir-Msla) & Opportunist* \\
\hline Nov 2003 & 5 & 5.0 & $47-62(6)$ & 4 (Ac-mysid) & Opportunist* \\
\hline \multicolumn{6}{|c|}{ Sprattus sprattus (Sspr) } \\
\hline Sep 2003 & 11 & 3.1 & 60-115 (5) & 4 (naup-Eaff) & Specialist $^{\text {ns }}$ \\
\hline \multicolumn{6}{|c|}{ Pomatoschistus microps (Pmic) } \\
\hline Jul 2003 & 10 & 7.8 & $27-37(15)$ & 9 (eggs-pol) & Specialist $^{\mathrm{ns}}$ \\
\hline Nov 2003 & 5 & 5.0 & $27-38(9)$ & 6 (eggs-isop) & Specialist $^{\text {ns }}$ \\
\hline Feb 2004 & 5 & 10.7 & $26-50(11)$ & 4 (eggs-amp) & Specialist ${ }^{\mathrm{ns}}$ \\
\hline Apr 2004 & 9 & 18.6 & $33-39(11)$ & $5(\mathrm{Ac}-\mathrm{amp})$ & Specialist $^{\mathrm{ns}}$ \\
\hline \multicolumn{6}{|c|}{ Pomatoschistus minutus (small) (PminS) } \\
\hline Sep 2003 & 11 & 3.1 & $23-39(8)$ & 5 (Ac-isop) & Specialist $^{\text {ns }}$ \\
\hline Feb 2004 & 5 & 10.7 & $26-38(21)$ & 5 (eggs-amp) & Specialist $^{\text {ns }}$ \\
\hline Jun 2004 & 10 & 13.1 & 21-39 (11) & 2 (Nint-amp) & Specialist $^{\mathrm{ns}}$ \\
\hline \multicolumn{6}{|c|}{ Pomatoschistus minutus (large) (PminL) } \\
\hline Jul 2003 & 10 & 7.8 & $40-73(17)$ & 9 (mol-shr) & Specialist $^{\text {ns }}$ \\
\hline Sep 2003 & 11 & 3.1 & $40-65(20)$ & 5 (cops-amp) & Specialist $^{\text {ns }}$ \\
\hline Nov 2003 & 5 & 5.0 & $41-65(11)$ & 5 (Msla-fish) & Opportunist* \\
\hline Feb 2004 & 5 & 10.7 & $41-60(5)$ & 3 (eggs-amp) & Specialist $^{\text {ns }}$ \\
\hline Jun 2004 & 10 & 13.1 & $40-55(19)$ & 3 (Nint-amp) & Opportunist* \\
\hline \multicolumn{6}{|c|}{ Argyrosomus regius (small) (AregS) } \\
\hline Jul 2003 & 10 & 7.8 & $30-104(68)$ & 9 (mol-fish) & Generalist $^{\text {ns }}$ \\
\hline Jun 2004 & 10 & 13.1 & $30-52(14)$ & 7 (Eaff-fish) & Generalist $^{\mathrm{ns}}$ \\
\hline \multicolumn{6}{|c|}{ Argyrosomus regius (large) (AregL) } \\
\hline Sep 2003 & 11 & 3.1 & $130-235(25)$ & 4 (Msla-fish) & Specialist $^{\text {ns }}$ \\
\hline Nov 2003 & 5 & 5.0 & $130-249(36)$ & 6 (Msla-fish) & Specialist $^{\text {ns }}$ \\
\hline Apr 2004 & 9 & 18.6 & $126-260(20)$ & 6 (Msla-shr) & Generalist $^{\mathrm{ns}}$ \\
\hline Jun 2004 & 10 & 13.1 & $118-263(38)$ & 9 (eggs-fish) & Specialist $^{\mathrm{ns}}$ \\
\hline \multicolumn{6}{|c|}{ Merlangius merlangus (Mmer) } \\
\hline Sep 2003 & 11 & 3.1 & 90-102 (5) & 3 (Ac-fish) & Specialist $^{\mathrm{ns}}$ \\
\hline Nov 2003 & 5 & 5.0 & $114-150(6)$ & 5 (Msla-fish) & Specialist $^{\text {ns }}$ \\
\hline \multicolumn{6}{|c|}{ Dicentrarchus labrax (Dlab) } \\
\hline Feb 2004 & 5 & 10.7 & $80-147(21)$ & 7 (Eaff-crab) & Specialist $^{\text {ns }}$ \\
\hline Apr 2004 & 9 & 18.6 & $83-140(8)$ & 5 (cops-fish) & Specialist $^{\mathrm{ns}}$ \\
\hline \multicolumn{6}{|c|}{ Dicentrarchus punctatus (Dpun) } \\
\hline Apr 2004 & 9 & 18.6 & 95-135 (8) & 5 (Msla-pol) & Opportunist* \\
\hline
\end{tabular}

- For the 2003 cohort of Argyrosomus regius, the diet was dominated numerically by Mesopodopsis slabberi $(78 \%)$ in July, by the shrimps Palaemon spp. in September $(54 \%)$ and November $(64 \%)$ and by Neomysis integer and Gammarus spp. in April (respectively, 44 and $28 \%$ ) and June (31 and 59\%). A. regius oscillated between a generalist and specialist feeding strategy.

- Dicentrarchus labrax fed essentially on the amphipods Gammarus spp. (24\%) and the shrimps Palaemon spp. $(32 \%)$ in February and on Gammarus spp. (57\%) and Neomysis integer (14\%) in April.

- The most abundant prey consumed by Merlangius merlangus were Mesopodopsis slabberi (88\%) in September and Palaemon spp. (50\%) in November. Dicen- trarchus labrax and M. merlangus always showed a specialist feeding strategy.

\section{Intraspecific feeding variability}

Intra-specific feeding variability according to fish size was tested for Pomatoschistus minutus and Argyrosomus regius. No significant difference was observed between the diets of the 2 size groups for $P$. minutus (p-values > 0.05), in contrast to $A$. regius, e.g. only small specimens fed on small zooplankton. Moreover, whatever its size, $P$. minutus presented a specialist strategy, whereas $A$. regius exhibited generalist predation when small and specialist predation when large. 


\section{DISCUSSION}

\section{Sample representativeness}

The present study was based on analyses, on the one hand, of fish stomach contents and, on the other hand, of hyperbenthic invertebrate samples, all from the same estuarine area, i.e. the upstream part of the saline Gironde estuary.

As in the saline areas of other European estuaries (Mees et al. 1995, McLusky \& Elliott 2004), hyperbenthic invertebrate samples were characterized by a low specific diversity and high densities, features which vary significantly over time. In previous investigations, temporal variability has been linked to fluctuations in environmental factors (David et al. 2005, Lobry et al. 2006). In addition, the specific compositions observed in 2003 (David 2006, Lobry et al. 2006) were similar to those observed in other Gironde estuary studies (Castel 1981, Sorbe 1981, Mees et al. 1995): the copepods consisted predominantly of Engraulis affinis in the spring and Acartia spp. in summer; the suprabenthos consisted of Neomysis integer in the spring and Mesopodopsis slaberri and Gammarus spp. in summer, which was similar to in other European estuaries (Soetaert \& van Rijswijk 1993, Mouny et al. 2000, Mouny \& Dauvin 2002). The study area was also representative for zooplankton and estuarine suprabenthos, which were fairly homogenous (David 2006). Thus, the samples collected give a good picture of hyperbenthic prey availability in the brackish part of the estuary for the pelagic and demersal fish selected, i.e. those feeding mainly on these communities.

For some fish species chosen, only a few specimens were included in the analysis due to a small number of individuals collected and/or because few individuals had a non-empty stomach, e.g. Sprattus sprattus and Dicentrarchus punctatus. Moreover, these samples were sometimes collected from only one particular trawl, i.e. concerned only a small part of the study area. However, for various reasons, these data have been taken into consideration in the present study:

- These species showed a low intra-group feeding variability, which can be explained by the characteristic of consumed hyperbenthic communities, i.e. few species, high densities. The statistical minimum of 5 individuals would therefore appear sufficient to define the diet of these species.

- In the brackish part of the Gironde estuary, there was no significant spatial variability in the prey communities either in composition or density (David et al. 2005, David 2006). Whatever the location of the fish sampling, analysis of their stomach contents was representative of the feeding strategy in the area studied.

- The choice of these species allowed us to make strategy comparisons between fish exhibiting ecologi- cal and feeding similarities, e.g. Sprattus sprattus and Engraulis encrasicolus and Dicentrarchus punctatus and D. labrax, and provided assumptions on the structuring mechanisms of fish communities in an estuarine environment.

\section{Inter- and intraspecific fish feeding variability}

Fish stomach content analyses provide more than just a snapshot of what and how much an individual has ingested at a given moment: they give essential information to help understanding of species feeding requirements and strategies.

Investigation of the diet compositions of the 8 main pelagic and demersal fish species during the study period in the Gironde estuary enabled us to show interspecific feeding variability. Despite the differences in taxa, geographical distribution and environmental conditions, similar feeding requirements have been observed in other estuarine and marine systems: the small pelagic fish Sprattus sprattus and Engraulis encrasicolus are zooplanktivores (e.g. Plounevez \& Champalbert 1999, Maes \& Ollevier 2002); demersal fish, represented by Argyrosomus regius, Dicentrarchus labrax, D. punctatus and Merlangius merlangus, consume hyperbenthos (Moore \& Moore 1976, Ktari et al. 1978, Cabral \& Ohmert 2001, Laffaille et al. 2001); and Pomatoschistus minutus and P. microps eat both mesozooplankton and hyperbenthic prey (Salgado et al. 2004, Leitão et al. 2006). This interspecific feeding variability could be linked to different body structures, i.e. ecotrophomorphology or ecomorphology (Wootton 1990). Morphological characteristics (e.g. position, shape and size of the mouth, shape and ability to protrude the jaw, body form and size) determine position in the water column, locomotive abilities and the size of prey they can intake (e.g. Schafer et al. 2002).

The present study highlights the fact that species that have ecological and trophic similarities (e.g. Sprattus sprattus and Engraulis encrasicolus, or Dicentrarchus labrax and D. punctatus) do not necessarily show diet overlap. Moreover, they present different feeding strategies. For example, the small pelagic fish $S$. sprattus is a specialist, whereas E. encrasicolus shows opportunistic predation strategies, and the demersal fish D. labrax is a specialist, whereas D. punctatus is an opportunist. This feeding strategy variability could narrow diet overlap, minimize interspecific competition and allow the co-occurrence of these species (Oscoz et al. 2006).

For species presenting ecological and morphological similarities and the same feeding strategies. Either (1) there is no feeding niche overlap. These cases occur when the species considered do not belong to the same 
size class, e.g. Pomatoschistus minutus and P. microps in November and February, Argyrosomus regius and Merlangius merlangus in September. Salgado et al. (2004) have already highlighted a decrease in feeding overlap between these 2 Pomatoschistus species due to an increased difference in length. Or (2) there is a feeding overlap when the resource is not limited, e.g. Pomatoschistus minutus and P. microps in February and Argyrosomus regius and Merlangius merlangus in November, the time of year when the environment is very poor in species numbers, but those that are present remain abundant, thus limiting any feeding competition.

Feeding variability according to size was tested only for Pomatoschistus minutus and Argyrosomus regius, and not for any other species, either because too few samples per species were available or because their size distribution was too uniform. No significant feeding variation was observed between the 2 size classes of $P$. minutus (small $<40 \mathrm{~mm}$; large $\geq 40 \mathrm{~mm}$ ). For this species, a dietary shift has already been highlighted for individuals with a total length $>50 \mathrm{~mm}$, with a progressive disappearance of copepods and a considerable increase in larger prey (Hamerlynck \& Cattrijsse 1994, Salgado et al. 2004). This size range $(\geq 50 \mathrm{~mm})$ has not been differentiated in the present study because of the small number of specimens. A variation in feeding according to fish length was observed for A. regius, but also for Merlangius merlangus with their growth in time. Their diets varied, with larger fish showing an increased consumption of larger prey. Body size effects on feeding shifts have already been identified for these predators (Quéro \& Vayne 1987, Pederson 1999, Cabral \& Ohmert 2001), as well as for Sprattus sprattus (Arrhenius 1996, Casini et al. 2004), Engraulis encrasicolus (Conway et al. 1998) and Dicentrarchus labrax (Kennedy \& Fitzmaurice 1972, Labourg \& Stequert 1973). Diet variations according to fish size have already been explained by ontogenetic changes in morphology, especially by the increase in predator gape width and swimming speed with the increase in predator size (e.g. Garrison \& Link 2000a, Pasquaud et al. 2004). The relative body size of the component species has often been identified as a major determinant of food-web structure (Warren \& Lawton 1987). Garrison \& Link (2000b) suggest that different size classes within a species may therefore be considered functionally as different species in terms of trophic dynamics. These diet changes are particularly marked when different ontogenetic stages are considered (e.g. Garrison \& Link 2000a, Woodward \& Hildrew 2002), but these have not been highlighted in this work.

The study of feeding strategies according to fish size reveals different behaviors for Argyrosomus regius (generalist/specialist) and Pomatoschistus minutus (specialist/opportunist). Marshall \& Elliott (1996), who studied the feeding ecology of the main fish species recorded in the Humber estuary (United Kingdom), also emphasized specialization by the largest specimens for some species and an increase in niche breadth with size for other species.

\section{Temporal feeding variability}

In relation to the naturally variable environmental conditions, estuarine biological communities exhibit distinctive temporal patterns at both low (David et al. 2005, 2006) and high trophic levels (see, for instance, Elliott \& Hemingway 2002, Lobry et al. 2006), suggesting that the resilience of estuarine ecosystems is linked to the temporal trophic structure and perhaps to fish species' ability to adapt their diet according to available prey in the environment.

As in other estuarine systems (e.g. Hajisamae et al. 2003, Hampel et al. 2005, West et al. 2006, Reum \& Essington 2008), the present work emphasizes a temporal variability in estuarine fish diets and thus in trophic topology. The use of the cross-calculation method enabled us to identify how fish exploit trophic resources according to time. As a result, most species were identified as specialist, whichever month is being considered. The present study therefore invalidates the common hypothesis that estuarine fish are generally opportunists (e.g. Moore \& Moore 1976, Cabral \& Ohmert 2001, Laffaille et al. 2001, Baldoa \& Drake 2002, Elliott \& Hemingway 2002). Only a minority of the pelagic and demersal fish community in the Gironde estuary - characterized by the marine juveniles Engraulis encrasicolus and Dicentrarchus punctatus and by the resident species Pomatoschistus minutus-were found to feed on the predominant abundant prey which differed from month to month.

This difference in conclusions, specialist versus opportunist, can be explained by the precision of the method used for the present study, as it enabled us to test whether, among all the prey that can be the most abundant in the system, a particular weight (size) range is selected. In the estuarine context, where specific diversities are low and densities are high, the use of this method to draw conclusions about fish feeding strategy would seem particularly appropriate.

It is interesting to note that this study reveals the specialist feeding strategy of Pomatoschistus microps and $P$. minutus, always described as opportunistic fish in the literature (e.g. Pihl 1985, Pasquaud et al. 2004, Leitão et al. 2006). Nevertheless, the dietary analysis for both size and time emphasizes the capacity of $P$. minutus to adapt its feeding strategy according to prey 
availability. We can assume that the other resident species $P$. microps is able to adapt too.

The present study highlights the specialist feeding strategy of the Sprattus sprattus, Merlangius merlangus and Dicentrarchus labrax species, whatever the month considered. This strategy had already been shown for $S$. sprattus, which may have a major impact on the zooplankton community (Brooks \& Dodson 1965, Rudstam et al. 1994, Casini et al. 2004). Thus, a decrease in the abundance of these 3 marine juvenile species or their absence from the system could be linked to a decrease in/disappearance of their preferential prey, associated with an increase in competition pressure (prey availability). For $S$. sprattus, a decrease in its zooplanktonic prey, as well as trophic competition pressure from Engraulis encrasicolus could explain its departure from the study area in November. The temporal segregation of $M$. merlangus and D. labrax, species that show feeding similarities, could also support this hypothesis. An ability to avoid niche overlap by spatio-temporal segregation has already been shown for these 2 species in relation to other fish species (Bromley et al. 1997, Cabral \& Ohmert 2001). These results suggest a structuring of the fish communities according to prey-predator relationships.

However, as suggested by prey abundances, shrimps are probably not limited in winter. The absence of Merlangius merlangus and Argyrosomus regius - also specialist but trending towards generalist - in February could be correlated with environmental conditions, especially low salinities and low water temperatures (Quéro \& Vayne 1987, Pasquaud 2006). These observations suggest that the fish assemblages in that brackish part of the estuary are structured more by abiotic factors than by trophic relationships during this period of the year. In other studies (e.g. Costa \& Elliott 1991, Thiel et al. 1995, Kupschus \& Tremain 2001, Harrison \& Whitfield 2006, Lobry et al. 2006), this estuarine fish community structuring has also been related to environmental variables, especially temperature and salinity, which depend on temporal variations in water flow (Lobry et al. 2006).

The estuarine fish communities are structured in time, both by environmental conditions and trophic relationships (Marshall \& Elliott 1996, Kimmerer 2002), but we can hypothesize that these structuring factors do not take effect on the same spatial scales as suggested by Martino \& Able (2003): 'large-scale patterns in the structure of estuarine fish assemblage are primarily a result of individual species' responses to dominate environmental gradients, as well as ontogenetic migrations, whereas smaller-scale patterns appear to be the result of habitat associations that are most likely driven by foraging, competition, and/or predator avoidance'. This remark confirms theoretical views on community structure, which maintain that physiologi- cal tolerances to environmental factors set up the community framework, while biotic interactions refine species distribution patterns within this structure (Weinstein et al. 1980, Menge \& Olson 1990) and underlines the need to consider the spatial feeding variability, which was not studied in this work.

\section{CONCLUSIONS}

Analysis of fish stomach contents gave a picture of the temporal patterns of the Gironde estuary fish food web, describing interspecific and intraspecific trophic relationships and the dynamics of the food-web structure. Comparisons of the relative abundance of prey in the stomach contents, numerical abundance of these prey in the environment and mean weight appear particularly relevant for studying fish feeding strategy in estuaries and assessing the trophic functions provided by this system for these species.

The present study highlights a strong trophic dynamism and suggests a resource partitioning dependent on predator/prey size (according to predator/prey life cycle), prey availability and predator presence (according to predator life cycle and environmental conditions). Optimization of available trophic resource use, a key element in estuarine resilience (Elliott \& Quintino 2007), is possible due to the temporal adaptation of this structural trophic web. This trophic dynamism could play a major role in the stability/resilience of this ecosystem (cf. Link 2002), as suggested by recent statements in the biodiversity-stability debate (see for instance Navarrete \& Berlow 2006, Elliott \& Quintino 2007).

In spite of their adaptation capacity, most fish species exhibited a specialist feeding strategy. In the Gironde estuary there are few invertebrate species. We can imagine that the loss of one species will affect the fish trophic web structure and hence the resilience of the system. Comparative spatial studies are envisaged, i.e. intra-system studies, or comparisons with other estuaries or marine systems, to examine whether our conclusions can be generalized, to give a better understanding of the mechanisms of prey-predator structuring and to ascertain the degree of marine fish species dependence on estuarine systems.

The present study has enabled us to go beyond the structural aspects of biological communities and access functional aspects, in accordance with some recent recommendations by de Jonge et al. (2006) and Elliott \& Quintino (2007) concerning the implementation of monitoring programs in estuarine areas. In addition, this approach provides the data needed to develop and/or validate trophic models (i.e. Lobry et al. 2008), in order to identify keystone species (Libralato et al. 2006) and predict the development of these systems. 
Acknowledgements. We thank B. Ballion, R. Le Barh, J. F. Bigot, F. Daverat, M. Lepage and everyone who took part in sampling surveys. This investigation was supported by the French Institute of Agricultural and Environmental Engineering Research (Cemagref), the Regional Council of Aquitaine and the Ecology and Economics of the Garonne basin program.

\section{LITERATURE CITED}

Arrhenius F (1996) Diet composition and food selectivity of 0-group herring (Clupea harengus L) and sprat (Sprattus sprattus L) in the northern Baltic Sea. ICES J Mar Sci 53: 701-712

Azémar F, Boulêtreau S, Lionard M, Muylaert K, Vyverman W, Meire P, Tackx M (2007) Looking for general trends in trophic interactions among estuarine micro- and mesozooplankton. J Plankton Res 29:i135-i147

Baird D, Ulanowicz RE (1993) Comparative study on the trophic structure, cycling and ecosystem properties of four tidal estuaries. Mar Ecol Prog Ser 99:221-237

Baldoa F, Drake P (2002) A multivariate approach to the feeding habits of small fishes in the Guadalquivir Estuary. J Fish Biol 61:21-32

Bromley PJ, Watson T, Hislop JRG (1997) Diel feeding patterns and the development of food webs in pelagic 0group cod (Gadus morhua L.), haddock (Melanogrammus aeglefinus L.), whiting (Merlangius merlangus L.), saithe (Pollachius virens L.), and Norway pout (Trisopterus esmarkii Nilsson) in the northern North Sea. ICES J Mar Sci 54:846-853

Brooks JL, Dodson SI (1965) Predation, body size and composition of plankton. Science 150:28-35

Cabral HN, Ohmert B (2001) Diet of juvenile meagre, Argyrosomus regius, within the Tagus estuary. Cah Biol Mar 42: 289-293

Casini M, Cardinale M, Arrhenius F (2004) Feeding preferences of herring (Clupea harengus) and sprat (Sprattus sprattus) in the southern Baltic Sea. ICES J Mar Sci 61: $1267-1277$

Castel J (1981) Aspects de l'étude écologique du plancton de l'estuaire de la Gironde. Oceanis 6:535-577

Chessel D, Dufour AB, Thioulouse J (2004) The ade4 package. I. One-table methods. R News 4:5-10. http://cran.rproject.org/doc/Rnews/

Conway DVP, Coombs SH, Smith C (1998) Feeding of anchovy Engraulis encrasicolus larvae in the northwestern Adriatic Sea in response to changing hydrobiological conditions. Mar Ecol Prog Ser 175:35-49

Cortès E (1997) A critical review of methods of studying fish feeding based on analysis of stomach contents: application to elasmobranch fishes. Can J Fish Aquat Sci 54:726-738

Costa MJ, Elliott M (1991) Fish usage and feeding in two industrialised estuaries - the Tagus, Portugal, and the Forth, Scotland. In: Elliott M, Ducrotoy JP (eds) Estuaries and coasts: spatial and temporal intercomparisons. Olsen and Olsen, Fredensborg, p 289-297

Dauvin JC, Ruellet T (2009) The estuarine quality paradox: Is it possible to define an ecological quality status for specific modified and naturally stressed estuarine ecosystems? Mar Pollut Bull 59:38-47

David V (2006) Variabilité spatio-temporelle du zooplancton dans l'estuaire de la Gironde et implications au sein du réseau trophique planctonique. PhD thesis, Université de Bordeaux I, Bordeaux

> David V, Sautour B, Chardy P, Leconte M (2005) Long-term changes of the zooplankton variability in a turbid environ- ment: the Gironde estuary (France). Estuar Coast Shelf Sci 64:171-184

David V, Sautour B, Galois R, Chardy P (2006) The paradox high zooplankton biomass-low vegetal particulate organic matter in high turbidity zones: What way for energy transfer? J Exp Mar Biol Ecol 333:202-218

> de Jonge VN, Elliott M, Brauer VS (2006) Marine monitoring: its shortcomings and mismatch with the EU water framework directive's objectives. Mar Pollut Bull 53:5-19

Elliott M, Hemingway K (eds) (2002) Fishes in estuaries. Blackwell, London

Elliott M, Quintino V (2007) The estuarine quality paradox, environmental homeostasis and the difficulty of detecting anthropogenic stress in naturally stressed areas. Mar Pollut Bull 54:640-645

Garrison LP, Link JS (2000a) Dietary guild structure of the fish community in the Northeast United States continental shelf ecosystem. Mar Ecol Prog Ser 202:231-240

Garrison LP, Link JS (2000b) Fishing effects on spatial distribution and trophic guild structure of the fish community in the Georges Bank region. ICES J Mar Sci 57:723-730

Hajisamae S, Chou LM, Ibrahim S (2003) Feeding habits and trophic organization of the fish community in shallow waters of an impacted tropical habitat. Estuar Coast Shelf Sci 58:89-98

Hamerlynck O, Cattrijsse A (1994) The food of Pomaroschistus minutus (Pisces, Gobiidae) in Belgian coastal waters, and a comparison with the food of its potential competitor P. lozanoi. J Fish Biol 44:753-771

> Hampel H, Cattrijsse A, Elliott M (2005) Feeding habits of young predatory fishes in marsh creeks situated along the salinity gradient of the Schelde estuary, Belgium and The Netherlands. Helgol Mar Res 59:151-162

> Harrison TD, Whitfield AK (2006) Temperature and salinity as primary determinants influencing the biogeography of fishes in South African estuaries. Estuar Coast Shelf Sci 66:335-345

Hooper DU, Chapin FS, Ewel JJ, Hector A and others (2005) Effects of biodiversity on ecosystem functioning: a consensus of current knowledge. Ecol Monogr 75:3-35

> Hurlbert ST (1978) The measurement of niche overlap and some relatives. Ecology 59:67-77

> Hynes HBN (1950) The food of freshwater sticklebacks (Gasterosteus aculeatus and Pygosteus pungitius) with a review of methods used in studies of the food of fishes. J Anim Ecol 19:36-58

Hyslop EJ (1980) Stomach contents analysis - a review of methods and their application. J Fish Biol 17:411-429

Irigoien X, Castel J (1995) Feeding rates and productivity of the copepod Acartia bifilosa in a highly turbid estuarythe Gironde (SW France). Hydrobiologia 311:115-125

Kennedy M, Fitzmaurice P (1972) The biology of the bass, Dicentrarchus labrax, in Irish waters. J Mar Biol Assoc UK 52:557-597

Kimmerer WJ (2002) Effects of freshwater flow on abundance of estuarine organisms: Physical effects or trophic linkages? Mar Ecol Prog Ser 243:39-55

Klein Tank A, Wijngaard JB, Konnen GP, Bohm R and others (2002) Daily dataset of 20th-century surface air temperature and precipitation series for the European Climate Assessment. Int J Climatol 22:1441-1453

Ktari MH, Bouain A, Quignard JP (1978) Régime alimentaire des loups (Poissons, Téléostéens, Serranidae) Dicentrarchus labrax (Linné, 1778) et Dicentrarchus punctatus (Bloch, 1892) des côtes tunisiennes. Bull Inst Natl Sci Tech Océanogr Pêches 5:5-15

Kupschus S, Tremain D (2001) Associations between fish 
assemblages and environmental factors in nearshore habitats of a subtropical estuary. J Fish Biol 58:1383-1403

Labourg PJ, Stequert B (1973) Régime alimentaire du bar Dicentrarchus labrax L. des réservoirs à poissons de la région d'Arcachon. Bull Ecol 4:187-194

Laffaille P, Lefeuvre JC, Schricke MT, Feunteun E (2001) Feeding ecology of 0-group sea bass, Dicentrarchus labrax, in salt marshes of Mont Saint Michel Bay (France). Estuaries 24:116-125

Leitão R, Martinho E, Neto JM, Cabral H, Marques JC, Pardal MA (2006) Feeding ecology, population structure and distribution of Pomatoschistus microps (Kroyer, 1838) and Pomatoschistus minutus (Pallas, 1770) in a temperate estuary, Portugal. Estuar Coast Shelf Sci 66:231-239

Libralato S, Christensen V, Pauly D (2006) A method for identifying keystone species in food web models. Ecol Modell 195:153-171

Lin HJ, Shao KT, Jan RQ, Hsieh HL, Chen CP, Hsieh LY, Hsiao YT (2007) A trophic model for the Danshuei River estuary, a hypoxic estuary in northern Taiwan. Mar Pollut Bull 54:1789-1800

Link J (2002) Does food web theory work for marine ecosystems? Mar Ecol Prog Ser 230:1-9

Livingston RJ (2002) Trophic organization in coastal systems. CRC Press, Boca Raton, FL

Lobry J, Mourand L, Rochard E, Elie P (2003) Structure of the Gironde estuarine fish assemblages: a comparison of European estuaries perspective. Aquat Living Resour 16:47-58

Lobry J, Lepage M, Rochard E (2006) From seasonal patterns to a reference situation in an estuarine environment: example of the small fish and shrimp fauna of the Gironde estuary (SW France). Estuar Coast Shelf Sci 70:239-250

Lobry J, David V, Pasquaud S, Lepage M, Sautour B, Rochard E (2008) Diversity and stability of an estuarine trophic network. Mar Ecol Prog Ser 358:13-25

Macdonald JS, Green RH (1983) Redundancy of variables used to describe importance of prey species in fish diets. Can J Fish Aquat Sci 40:635-637

> Maes J, Ollevier F (2002) Size structure and feeding dynamics in estuarine clupeoid fish schools: field evidence for the school trap hypothesis. Aquat Living Resour 15:211-216

Marshall S, Elliott M (1996) The structure of the fish assemblage in the Humber estuary, United Kingdom. Publ Espec Inst Esp Oceanogr 21:231-242

Martino EJ, Able KW (2003) Fish assemblages across the marine to low salinity transition zone of a temperate estuary. Estuar Coast Shelf Sci 56:969-987

McLusky DS, Elliott M (2004) The estuarine ecosystem: ecology, threats and management. Oxford University Press, Oxford

Mees J, Fockedey N, Hamerlynck O (1995) Comparative study of the hyperbenthos of three European estuaries. Hydrobiologia 311:153-174

Menge BA, Olson AM (1990) Role of scale and environmental factors in regulation of community structure. Trends Ecol Evol 5:52-57

- Moore JW, Moore IA (1976) The basis of food selection in some estuarine fishes. Eels, Anguilla anguilla (L.), whiting, Merlangius merlangus (L.), sprat, Sprattus sprattus (L.) and stickleback, Gasterosteus aculeatus (L.). J Fish Biol 9:375-390

Mouny P, Dauvin JC (2002) Environmental control of mesozooplankton community structure in the seine estuary (English Channel). Oceanol Acta 25:13-22

Mouny P, Dauvin JC, Zouhiri S (2000) Benthic boundary layer fauna from the Seine estuary (eastern English Channel, France): spatial distribution and seasonal changes. J Mar
Biol Assoc UK 80:959-968

- Navarrete SA, Berlow EL (2006) Variable interaction strengths stabilize marine community pattern. Ecol Lett 9: 526-536

Oscoz J, Leunda PM, Miranda R, Escala MC (2006) Summer feeding relationships of the co-occurring Phoxinus phoxinus and Gobio lozanoi (Cyprinidae) in an Iberian river. Folia Zool (Brno) 55:418-432

Pasquaud S (2006) Les relations trophiques: éléments de structuration des peuplements ichtyologiques en milieu estuarien - Application à l'estuaire de la Gironde. These de doctorat, Université de Bordeaux 1, Bordeaux

Pasquaud S, Girardin M, Elie P (2004) Diet of gobies of the genus Pomatoschistus (P. microps and P. minutus), in the Gironde estuary (France). Cybium 28:99-106

Pasquaud S, Lobry J, Elie P (2007) Facing the necessity of describing estuarine ecosystems: a review of food web ecology study techniques. Hydrobiologia 588:159-172

Pasquaud S, Elie P, Jeantet C, Billy I, Martinez P, Girardin M (2008) A preliminary investigation of the fish food web in the Gironde estuary, France, using dietary and stable isotope analyses. Estuar Coast Shelf Sci 78:267-279

Pederson J (1999) Diet comparison between pelagic and demersal whiting in the North Sea. J Fish Biol 63:197-212

> Pihl L (1985) Food selection and consumption of mobile epibenthic fauna in shallow marine areas. Mar Ecol Prog Ser 22:169-179

Plounevez S, Champalbert G (1999) Feeding behaviour and trophic environment of Engraulis encrasicolus (L.) in the Bay of Biscay. Estuar Coast Shelf Sci 49:177-191

Quéro JC, Vayne JJ (1987) Le maigre, Argyrosomus regius (Asso, 1801) (Pisces, Perciformes, Sciaenidae) du Golfe de Gascogne et des eaux plus septentrionnales. Rev Trav Inst Pech Marit 49:35-66

Reum JCP, Essington TE (2008) Seasonal variation in guild structure of the Puget Sound demersal fish community. Estuaries Coasts 31:790-801

Rudstam LG, Aneer G, Hildén M (1994) Top-down control in the pelagic Baltic ecosystems. Dana 10:105-129

Salgado JP, Cabral HN, Costa MJ (2004) Feeding ecology of the gobies Pomatoschistus minutus (Pallas, 1770) and Pomatoschistus microps (Kroyer, 1838) in the upper Tagus estuary, Portugal. Sci Mar 68:425-434

Salomon JN (2002) L'inondation dans la basse vallée de la Garonne et l'estuaire de la Gironde lors de la 'tempête du siècle' (27-28 décembre 1999). Géomorphologie: relief, processus, environnement 2:127-134

Sautour B, Castel J (1995) Comparative spring distribution of zooplankton in three macrotidal European estuaries. Hydrobiologia 311:139-151

Schafer LN, Platell ME, Valesini FJ, Potter IC (2002) Comparisons between the influence of habitat type, season and body size on the dietary compositions of fish species in nearshore marine waters. J Exp Mar Biol Ecol 278:67-92

> Soetaert K, Van Rijswijk P (1993) Spatial and temporal patterns of the zooplankton in the Westerschelde estuary. Mar Ecol Prog Ser 97:47-59

Sorbe JC (1981) La macrofaune vagile de l'estuaire de la Gironde: distribution et migration des espèces, modes de reproduction et régimes alimentaires. Oceanis 6:579-592

Sottolichio A (1999) Modélisation de la dynamique des structures turbides (bouchon vaseux et crème de vase) dans l'estuaire de la Gironde. Thèse de doctorat, Université de Bordeaux I, Bordeaux

Thiel R, Sepulveda A, Kafemann R, Nellen W (1995) Environmental factors as forces structuring the fish community of the Elbe Estuary. J Fish Biol 46:47-69 
Wallace RK (1981) An assessment of diet-overlap indexes. Trans Am Fish Soc 110:72-76

Wallace H, Ramsay JS (1983) Reliability in measuring diet overlap. Can J Fish Aquat Sci 40:347-351

Warren PH, Lawton JH (1987) Invertebrate predator-prey body size relationships - an explanation for uppertriangular food webs and patterns in food web structure. Oecologia 74:231-235

Weinstein MP, Weiss SL, Walters MF (1980) Multiple determinants of community structure in shallow marsh habitats, Cape Fear River Estuary, North Caraolina, USA. Mar Biol 58:227-243
West JB, Bowen GJ, Cerling TE, Ehleringer JR (2006) Stable isotopes as one of nature's ecological recorders. Trends Ecol Evol 21:408-414

Wolff M, Koch V, Isaac V (2000) A trophic flow model of the Caeté mangrove estuary (North Brazil) with considerations for the sustainable use of its resources. Estuar Coast Shelf Sci 50:789-803

Woodward G, Hildrew AG (2002) Body-size determinants of niche overlap and intraguild predation within a complex food web. J Anim Ecol 71:1063-1074

Wootton RJ (1990) Ecology of teleost fishes. Chapman \& Hall, London

Appendix 1. Relative abundance diet composition $(\% N)$ of the main pelagic and demersal fish according to size and time in the upstream area of the saline Gironde estuary. See Table 2 for abbreviations

\begin{tabular}{|c|c|c|c|c|c|c|c|c|c|c|}
\hline & \multicolumn{4}{|c|}{$\longrightarrow$ Jul $2003-$} & \multirow[b]{2}{*}{ Eenc } & \multirow[b]{2}{*}{ Sspr } & \multicolumn{2}{|c|}{ - Sep 2003} & \multirow[b]{2}{*}{ AregL } & \multirow[b]{2}{*}{ Mmer } \\
\hline & Eenc & Pmic & PminL & AregS & & & Pmins & PminL & & \\
\hline Size range $(\mathrm{TL} ; \mathrm{mm})$ & $38-127$ & $27-37$ & $40-73$ & $30-104$ & $45-77$ & $60-115$ & $23-39$ & $40-65$ & $130-235$ & $90-102$ \\
\hline Number of full stomachs & 18 & 15 & 17 & 68 & 9 & 5 & 8 & 20 & 29 & 5 \\
\hline \multicolumn{11}{|l|}{ Zooplankton } \\
\hline Eggs & & 40 & & & & & & & & \\
\hline Nauplius larvae & 44.4 & & 2.8 & & 2.4 & 54.4 & & & & \\
\hline Mysis larvae & & & & 1.7 & & & & & & \\
\hline Mollusk eggs & 39.6 & 24.4 & 38.9 & 0.3 & & & & & & \\
\hline Mollusk larvae & 1.5 & & & & & & & & & \\
\hline Polychaete larvae & & & & 0.2 & & & & & & \\
\hline Cirriped larvae & 8.3 & 11.1 & 2. 8 & & & 0.3 & & & & \\
\hline \multicolumn{11}{|l|}{ Copepods } \\
\hline Eurytemora affinis & & 13.3 & & & & 3.9 & 10 & 3.4 & & \\
\hline Acartia spp. & 4.4 & & & 4.7 & 94 & 41.7 & 10 & & & 5.9 \\
\hline Copepods ind. & & & & & & & & 3.4 & & \\
\hline \multicolumn{11}{|l|}{ Hyperbenthos } \\
\hline \multicolumn{11}{|l|}{ Mysidacea } \\
\hline Neomysis integer & 1.5 & & 11.1 & 4.3 & & & & 10.3 & & \\
\hline Mesopodopsis slabberi & 0.8 & 2.2 & 22.2 & 78.5 & 3.6 & & 60 & 79.3 & 22.2 & 88.2 \\
\hline Mysids ind. & & 2.2 & 8.3 & & & & 10 & & & \\
\hline \multicolumn{11}{|l|}{ Isopoda } \\
\hline Synidotea laticauda & & 2.2 & & & & & 10 & & 6.4 & \\
\hline Isopods ind. & & & 2.8 & & & & & & & \\
\hline \multicolumn{11}{|l|}{ Amphipoda } \\
\hline Gammarus spp. & & 2.2 & 5.6 & 0.2 & & & & 3.4 & & \\
\hline \multicolumn{11}{|l|}{ Decapoda natantia } \\
\hline Palaemon spp. & & & & 0.3 & & & & & 54.1 & \\
\hline Crangon crangon & & & 2.8 & 9.5 & & & & & 9.2 & \\
\hline \multicolumn{11}{|l|}{ Nekton } \\
\hline Teleost fishes & & & & 0.2 & & & & & 8.3 & 5.9 \\
\hline \multicolumn{11}{|l|}{ Benthos } \\
\hline \multicolumn{11}{|l|}{ Annelida Polychaeta } \\
\hline Nereis succinea & & 2.2 & 2.8 & & & & & & & \\
\hline \multicolumn{11}{|l|}{ Other } \\
\hline Pollen & & 0.1 & & & & & & & & \\
\hline
\end{tabular}


Appendix 1 (continued)

\begin{tabular}{|c|c|c|c|c|c|c|c|c|c|}
\hline & \multirow[b]{2}{*}{ Eenc } & \multirow[b]{2}{*}{ Pmic } & \multirow{2}{*}{$\begin{array}{l}\text { Nov } 2003 \\
\text { PminL }\end{array}$} & \multirow[b]{2}{*}{ AregL } & \multirow[b]{2}{*}{ Mmer } & \multirow[b]{2}{*}{ Pmic } & \multirow{2}{*}{$\begin{array}{c}\text { Feb } \\
\text { PminS }\end{array}$} & \multirow{2}{*}{$\begin{array}{l}004- \\
\text { PminL }\end{array}$} & \multirow[b]{2}{*}{ Dlab } \\
\hline & & & & & & & & & \\
\hline Size range $(\mathrm{TL} ; \mathrm{mm})$ & $42-62$ & $27-38$ & $41-65$ & $130-249$ & $114-150$ & $26-50$ & $26-38$ & $41-60$ & $80-447$ \\
\hline Number of full stomachs & 6 & 9 & 11 & 36 & 6 & 11 & 21 & 5 & 21 \\
\hline \multicolumn{10}{|l|}{ Zooplankton } \\
\hline $\begin{array}{l}\text { Eggs } \\
\text { Copepods }\end{array}$ & & 38.5 & & & & 4.2 & 1.4 & 15.4 & \\
\hline Eurytemora affinis & 88.3 & 55.1 & & & & 94 & 84.2 & 82.3 & 7.4 \\
\hline Acartia spp. & 7.4 & & & & & & 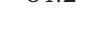 & & . \\
\hline Copepods ind. & & 1. 3 & & & & & 13.7 & & \\
\hline Hyperbenthos & & & & & & & & & \\
\hline $\begin{array}{l}\text { Mysidacea } \\
\text { Neomysis integer }\end{array}$ & & & & & & & & & \\
\hline Neomysis integer & & & 5.3 & 5.4 & & & & & \\
\hline $\begin{array}{l}\text { Mesopodopsis slabberi } \\
\text { Schystomysis spp. }\end{array}$ & 3.2 & & 36.8 & $\begin{array}{c}10 \\
1\end{array}$ & 10 & 0.6 & 0.2 & & \\
\hline Mysids ind. & 1.7 & 1.3 & 15.8 & 2.7 & & & & & 0.8 \\
\hline Isopoda & & & & & & & & & \\
\hline Synidotea laticauda & & & 15.8 & 3.6 & & & & & \\
\hline Amphipoda & & & & & & & & & \\
\hline $\begin{array}{l}\text { Gammarus spp. } \\
\text { Amphipods ind. }\end{array}$ & & & 21.5 & 1.8 & 10 & 1.2 & 0.4 & 2.3 & $\begin{array}{l}24.4 \\
2.16\end{array}$ \\
\hline Decapoda natantia & & & & & & & & & \\
\hline Palaemon spp. & & & & 64.5 & 50 & & & & 31.6 \\
\hline Crangon crangon & & & & 10 & 18.2 & & & & 6.1 \\
\hline Nekton & & & & & & & & & \\
\hline Teleost fishes & & & 5.3 & 1 & 10 & & & & \\
\hline Epibenthos & & & & & & & & & \\
\hline Isopoda & & & & & & & & & \\
\hline Cyathura carinata & & 1.3 & & & & & & & \\
\hline Sphaeroma serratum & & & & & & & & & 3.5 \\
\hline Amphipoda & & & & & & & & & \\
\hline Corophium volutator & & 2.6 & & & & & & & 19.8 \\
\hline Decapoda brachyura & & & & & & & & & \\
\hline Pachygrapsus marmoratus & & & & & & & & & 1.5 \\
\hline Rhithropanopeus harrisii & & & & & & & & & 0.8 \\
\hline Crabs ind. & & & & & & & & & 0.8 \\
\hline Annelida polychaeta & & & & & & & & & \\
\hline Nereis spp. & & & & & & & & & 0.8 \\
\hline Polychaetes ind. & & & & & 4.5 & & & & \\
\hline & & & - Apr & 2004 & & & - Jun & $004-$ & \\
\hline & & Pmic & Dlab & Dpun & AregL & PminS & PminL & AregS & AregL \\
\hline Size range $(\mathrm{TL} ; \mathrm{mm})$ & & $33-39$ & $83-140$ & $92-135$ & $125-260$ & $21-39$ & $40-55$ & $30-52$ & $118-263$ \\
\hline Number of full stomachs & & 11 & 8 & 5 & 20 & 11 & 19 & 14 & 38 \\
\hline Zooplankton & & & & & & & & & \\
\hline Eggs & & & & & & & & & 0.8 \\
\hline Mysis larvae & & & & & & & & 2.7 & 0.7 \\
\hline Copepods & & & & & & & & & \\
\hline Eurytemora affinis & & 62.2 & & & & & & 18.9 & \\
\hline Acartia spp. & & 8.2 & & & & & & & \\
\hline Copepods ind. & & & 7.1 & & & & & & \\
\hline Ichtyoplankton & & & & & & & & 20.3 & \\
\hline $\begin{array}{l}\text { Hyperbenthos } \\
\text { Mysidacea }\end{array}$ & & & & & & & & & \\
\hline $\begin{array}{l}\text { Mysidacea } \\
\text { Neomysis integer }\end{array}$ & & & & & 44.1 & 17.6 & 28 & & \\
\hline $\begin{array}{l}\text { Neomysis integer } \\
\text { Mesopodopsis slabberi }\end{array}$ & & 5.4 & 14.3 & 17.6 & $\begin{array}{c}44.1 \\
4.1\end{array}$ & & 28 & 36.5 & 31.4 \\
\hline $\begin{array}{l}\text { Mesopodopsis slabberi } \\
\text { Mysids ind. }\end{array}$ & & & & 69.4 & $\begin{array}{l}4.1 \\
1.4\end{array}$ & & & 8. 2 & 0.3 \\
\hline $\begin{array}{l}\text { Mysids ind. } \\
\text { Isopoda }\end{array}$ & & 5.4 & & & 1.4 & & & & 0.13 \\
\hline Synidotea laticauda & & & 7.1 & 2.3 & 2.7 & & & & 0.5 \\
\hline Sphaeroma serratum & & & & & & & & 4.5 & \\
\hline Amphipoda & & & & & & & & & \\
\hline Gammarus spp. & & 18.9 & 57.1 & 8.2 & 27.6 & 82.3 & 64 & 9.5 & 59.2 \\
\hline $\begin{array}{l}\text { Corophium volutator } \\
\text { Bathyporeia spp. }\end{array}$ & & & & 12 & 3.4 & & & & \\
\hline $\begin{array}{l}\text { Batnyporela spp. } \\
\text { Amphipods ind. }\end{array}$ & & & & 1.2 & & & 8 & & \\
\hline Decapoda natantia & & & & & & & & & \\
\hline Palaemon spp. & & & & & 6.9 & & & & 0.5 \\
\hline Crangon crangon & & & 7.1 & & 10.3 & & & & 5.1 \\
\hline Nekton & & & & & & & & & \\
\hline Teleost fishes & & & 7.1 & & & & & & 1.6 \\
\hline Benthos & & & & & & & & & \\
\hline Annelida polychaeta & & & & & & & & & \\
\hline Nereis succinea & & & & 1.2 & & & & & 0.4 \\
\hline
\end{tabular}

